\title{
Effect of urea-N on growth and indoleacetic acid production of Stenotrophomonas maltophilia (Sb16) isolated from rice growing soils in Malaysia
}

\author{
Radziah Othman ${ }^{1,2}$ *, Umme Aminun Naher ${ }^{2}$, and Siti Zuraidah Yusoff ${ }^{1}$
}

Growth and activity of $\mathrm{N}_{2}$-fixing bacteria can be affected by $\mathrm{N}$ fertilizer application. A study was conducted at Universiti Putra Malaysia, Malaysia, to determine the effect of urea-N on the growth and indoleacetic acid (IAA) production of diazotrophic Stenotrophomonas maltophilia strain Sb16 (accession number, JQ820255), previously isolated from rice (Oryza sativa L.) growing soils of Malaysia. Five rates of $\mathrm{N}$ from urea fertilizer were applied (0, 50, 100, 150, and 200 kg $\left.\mathrm{ha}^{-1}\right)$ to the flooded rice soil and incubated in the control environment for $6 \mathrm{wk}$. Results showed that the population growth increased with increased $\mathrm{N}$ rates and highest population $\left(8.2 \log _{10} \mathrm{cfu} \mathrm{mL}^{-1}\right)$ recorded in soil-standing water at the second week of incubation. The population decreased with the reduction of total N. Soil and soil water $\mathrm{pH}$ increased from 7.1 to 8.4 at the first week of incubation. Production of indoleacetic acid was significantly reduced with $\mathrm{N}$ fertilizer application. The highest indoleacetic acid $\left(2.6 \mathrm{mg} \mathrm{mL}^{-1}\right)$ was produced in the control treatment. Application of high rates of $\mathrm{N}$ fertilizer increased the population of diazotrophic strain Sb16 but significantly reduced indoleacetic acid production.

Key words: Incubation study, paddy soil, diazotroph.

\section{INTRODUCTION}

Rice (Oryza sativa L.) is one of the major staple food crops in the world (Wang et al., 2004), and $\mathrm{N}$ is the most important input for high yield. It is known that rice requires $1 \mathrm{~kg} \mathrm{~N}$ to produce $15-20 \mathrm{~kg}$ of grain. Yields per hectare are critically dependent on the nature, and amount and timing of $\mathrm{N}$ supply (George et al., 1992). Urea is the most commonly used $\mathrm{N}$ fertilizer in rice cultivation, produced in granular or pellet forms, and is coated with a non-hygroscopic inert material. After applied to the soil, its $\mathrm{N}$ is rapidly changed into ammonia.

Wetland rice ecosystem is unique where $\mathrm{N}$ can be supplied to plant through biological $\mathrm{N}$ fixation (BNF). Rice plant naturally associates with free living $\mathrm{N}_{2}$-fixing bacteria (diazotrophs). The rice ecosystem harbors diverse groups of diazotrophs and BNF is a spontaneous process in lowland rice ecosystem where adequate $\mathrm{C}$ sources are available (Kennedy et al., 2004).

Excessive use of $\mathrm{N}$ fertilizers is now known to promote $\mathrm{NO}_{3}^{-}$leaching, $\mathrm{NH}_{3}$ volatilization and nitrous oxide $\left(\mathrm{N}_{2} \mathrm{O}\right)$ emission in rice cropping system and can also affect the BNF process (Saikia and Vanita, 2007). Currently, $1-2 \%$ of the world's fossil energy is used for fertilizer production. The importance of BNF technology can play a role in substituting commercially available $\mathrm{N}$

\footnotetext{
${ }^{1}$ Universiti Putra Malaysia, Faculty of Agriculture, Department of Land Management, 43400 Serdang, Selangor, Malaysia. "Corresponding author (radziah@upm.edu.my).

${ }^{2}$ Universiti Putra Malaysia, Institute of Tropical Agriculture, 43400 Serdang, Selangor, Malaysia.

Received: 14 September 2012.

Accepted: 14 February 2013.

doi:10.4067/S0718-58392013000200016.
}

fertilizer use in rice culture. The rates of $\mathrm{N}_{2}$ fixation by free-living and associative diazotrophs in rice fields are low compared with the rates of $\mathrm{N}_{2}$ fixation by legumes (Bohlool et al., 1992). However, recent study shows that free living diazotrophs can supplement about $40 \%$ of total $\mathrm{N}$ to the rice (Naher et al., 2011). Previous study reported that high levels of mineral $\mathrm{N}$ caused a significant decrease in the $\mathrm{N}_{2}$ fixation as measured by acetylene reduction activity (ARA) due to the inhibition of nitrogenase enzyme synthesis (Junior et al., 2000). The process of $\mathrm{N}_{2}$ fixation by free-living bacteria as well as by symbiotic associations is inhibited in the presence of fixed $\mathrm{N}$ especially ammonium.

Association of diazotrophs improves plant growth by several mechanisms and one of the mechanisms is production of phytohormone such as indoleacetic acid (IAA). Application of $\mathrm{N}$ fertilizer is essential for high rice production but excessive use of $\mathrm{N}$ may bring adverse effects on the ecosystem, bacterial $\mathrm{N}_{2}$-fixing activity and IAA production. The objective of this study was to determine the effect of different levels of urea fertilizer on the growth, $\mathrm{N}_{2}$ fixation and indoleacetic acid production of local diazotroph strain Sb16 in paddy soil.

\section{MATERIALS AND METHODS}

\section{Inoculum preparation}

The bacterial strain Stenotrophomonas maltophilia Sb16 (accession number JQ820255) was previously isolated from Tanjong Karang Rice growing area in Malaysia (Naher et al., 2008). The bacterial strain (Sb16) used was Gram negative rod, with cellulolytic enzyme activity, high IAA $\left(60 \mathrm{mg} \mathrm{L}^{-1}\right)$, nitrogenase activity of $1.4 \times 10^{-7} \mu \mathrm{mol} \mathrm{C}_{2} \mathrm{H}_{4}{ }^{-1}$ $\mathrm{cfu}^{-1} \mathrm{~h}^{-1}$ and $43 \%$ Nfda (Naher et al., 2009; 2011). Starter 
culture was prepared by growing pure culture of Sb16 in Jensen's $\mathrm{N}$-free broth for $36 \mathrm{~h}$. Composition of broth $\left(\mathrm{L}^{-1}\right)$ : $20.0 \mathrm{~g}$ sucrose, $1.0 \mathrm{~g} \mathrm{~K}_{2} \mathrm{HPO}_{4}, 0.5 \mathrm{~g} \mathrm{MgSO}_{4} \cdot 7 \mathrm{H}_{2} \mathrm{O}, 0.5 \mathrm{~g}$ $\mathrm{NaCl}, 0.1 \mathrm{~g} \mathrm{FeSO}_{4}, 0.005 \mathrm{~g} \mathrm{Na}_{2} \mathrm{MoO}_{4}, 2.0 \mathrm{~g} \mathrm{CaCO}_{3}$. pH was adjusted to 6.8-7.0. One milliliter of the starter culture containing approximately $2 \times 10^{7} \mathrm{cfu} \mathrm{mL}^{-1}$ was transferred to a $100 \mathrm{~mL}$ flask containing $50 \mathrm{~mL}$ of Jensen's $\mathrm{N}$-free broth medium and allowed to grow to exponential growth phase.

\section{Soil inoculation and incubation}

Bacteria cells were harvested, washed with phosphate buffer solution ( $0.85 \%$ PBS), and immediately suspended into PBS solution. Before applied inoculum optical density $\left(\mathrm{OD}_{600}\right)$ of washed cells were checked and adjusted to 0.1 and the population was confirmed by cell enumeration using drop plate method on $\mathrm{N}$-free media (Somasegaran and Hoben, 1985). Approximately $1 \times 10^{9} \mathrm{cfu} \mathrm{mL}^{-1}$ of live washed cells was applied in to each treatment using sterilized pipette. The soil used in the study contained $0.1 \% \mathrm{~N}$ and $\mathrm{pH}$ 6.3. About $100 \mathrm{~g}$ of autoclaved sieved (4 mm) soil was placed in 250 $\mathrm{mL}$ conical flask and was flooded with $100 \mathrm{~mL}$ sterilized distilled water to maintain a standing water of about $3 \mathrm{~cm}$. The bacterial treatments contained five levels of urea-N $\left(0,50,100,150\right.$, and $\left.200 \mathrm{~kg} \mathrm{ha}^{-1}\right)$. The experimental units were kept in incubator maintaining temperature $28 \pm 2{ }^{\circ} \mathrm{C}$ for $6 \mathrm{wk}$. The flasks were destructively sampled weekly. Bacterial population in soil and soil-standing water, total $\mathrm{N}$ and IAA production were determined.

\section{Determination of bacterial population}

For soil population, $10 \mathrm{~g}$ of soil from the bottom of the flask was transferred into a conical flask containing $95 \mathrm{~mL}$ sterilized distilled water, while, for soil-standing water, $1.0 \mathrm{~mL}$ water was transferred into flask containing $99 \mathrm{~mL}$ sterilized water. The mixture was shaken vigorously on a rotary shaker for $10 \mathrm{~min}$ to suspend bacterial cells. A serial dilution was prepared and population was determined using the plate count method in $\mathrm{N}$-free medium (Somasegaran and Hoben, 1985). Composition of the medium is $\left(\mathrm{L}^{-1}\right)$ $5 \mathrm{~g}$ malic acid, $0.5 \mathrm{~g} \mathrm{~K}_{2} \mathrm{HPO}_{4}, 0.2 \mathrm{~g} \mathrm{MgSO}_{4} \cdot 7 \mathrm{H}_{2} \mathrm{O}, 0.1 \mathrm{~g}$ $\mathrm{NaCl}, 0.02 \mathrm{~g} \mathrm{CaCl}_{2}$ and $0.5 \%$ bromothymol blue in $0.2 \mathrm{~N}$ $\mathrm{KOH}(2 \mathrm{~mL}), 1.64 \% \mathrm{Fe}-E D T A$ solution $(4 \mathrm{~mL})$ and $20 \mathrm{~g}$ agar. The change of media color from dark green to blue and growth of colony was indicating the $\mathrm{N}_{2}$-fixing activity of the bacteria.

\section{Determination of soil/water $\mathbf{p H}$ and total $\mathbf{N}$}

Soil $\mathrm{pH}$ and soil-standing water were determined at weekly intervals. For total $\mathrm{N}$ determination soil and soil-standing water samples were digested $\left(\mathrm{H}_{2} \mathrm{SO}_{4}-\mathrm{H}_{2} \mathrm{O}_{2}\right.$ acid digestion) and total $\mathrm{N}$ was determined using Autoanalyzer (QuickChem 8000 series FIA System, Lachat Instrument, Loveland, Colorado, USA).

\section{Extraction of IAA from soil and water}

The IAA concentration of soil sample was determined using modified method of Sarwar et al. (1992). Three grams of soil were placed into a $50 \mathrm{~mL}$ Erlenmeyer flask and treated with $6 \mathrm{~mL}$ of phosphate buffer $(0.2 \mathrm{M}, \mathrm{pH} 7.0)$ and $4 \mathrm{~mL}$ of L-tryptophan solution (5.3 g L-tryptophan $\mathrm{kg}^{-1}$ soil). The flask was covered with parafilm and incubated in darkness at room temperature $\left( \pm 28{ }^{\circ} \mathrm{C}\right)$ for $12 \mathrm{~h}$ on a shaker $(\sim 150 \mathrm{rpm})$. After incubation, flask contents were treated with $2 \mathrm{~mL}$ trichloroacetic acid (5 g $100 \mathrm{~mL}^{-1} \mathrm{H}_{2} \mathrm{O}$ ) to terminate the reaction and $1 \mathrm{~mL}$ calcium chloride $(0.5 \mathrm{M})$ to facilitate filtration. The soil standing water was filtered through Whatman Filter paper nr 2. A buffer solution without incubation of soil was also prepared as a standard solution. For soil and soil standing water sample, approximately $2 \mathrm{~mL}$ water supernatant were mixed with Salkowski reagent (Gordon and Weber, 1951) and the mixture was allowed to stand $30 \mathrm{~min}$ for color development. The intensity of the color development was measured at $535 \mathrm{~nm}$ by using a spectrophotometer (Milton Roy, Rochester, New York, USA). The amount of L-tryptophan-derived auxins content in soil and soil standing water was determined as IAA-equivalents (mg $\mathrm{kg}^{-1}$ soil) using standard IAA solution.

\section{Statistical analysis}

The experiment was conducted in factorial completely randomized design with three replicates. All experimental data were statistically analyzed by ANOVA using SAS (9.1 version) statistical software. Treatment means were compared using Tukey's test ( $\mathrm{p} \leq 0.05)$.

\section{RESULTS AND DISCUSSION}

\section{Population of diazotrophs Sb16}

Application of different levels of urea-N increased population of Sb16. However, population differed significantly with time (Figure 1). In general bacterial population in the soil-standing water was higher than in soil. Significantly high population growth was observed in soil treated with $200 \mathrm{~kg} \mathrm{~N}^{-1}$. Soil applied with urea-N showed higher population growth at first week and then decreased with increasing time. On the other hand, population in soil standing water was found high at second week of incubation. It is known that population of the diazotrophs can be affected by several factors including $\mathrm{pH}$, temperature, nutrients, water, oxygen, and metabolic compounds (Döbereiner and Pedrosa, 1987). This study showed that population of Sb16 was indeed affected by the use of urea-N in the soil. The bacterial population decreased with increasing incubation time probably due to urea-N reduction over time and it was an important nutrient source for bacteria growth. Compared to soil, soil standing water maintained higher population as the applied bacteria contributed some of $\mathrm{NH}_{4}-\mathrm{N}$ to the water. Previous study also showed that application of Sb16 increased $\mathrm{NH}_{4}-\mathrm{N}$ level in soil water (Othman et al., 2012).

There was a positive significant relationship found between $\mathrm{N}$ rates and population of bacteria (Figure 2). 

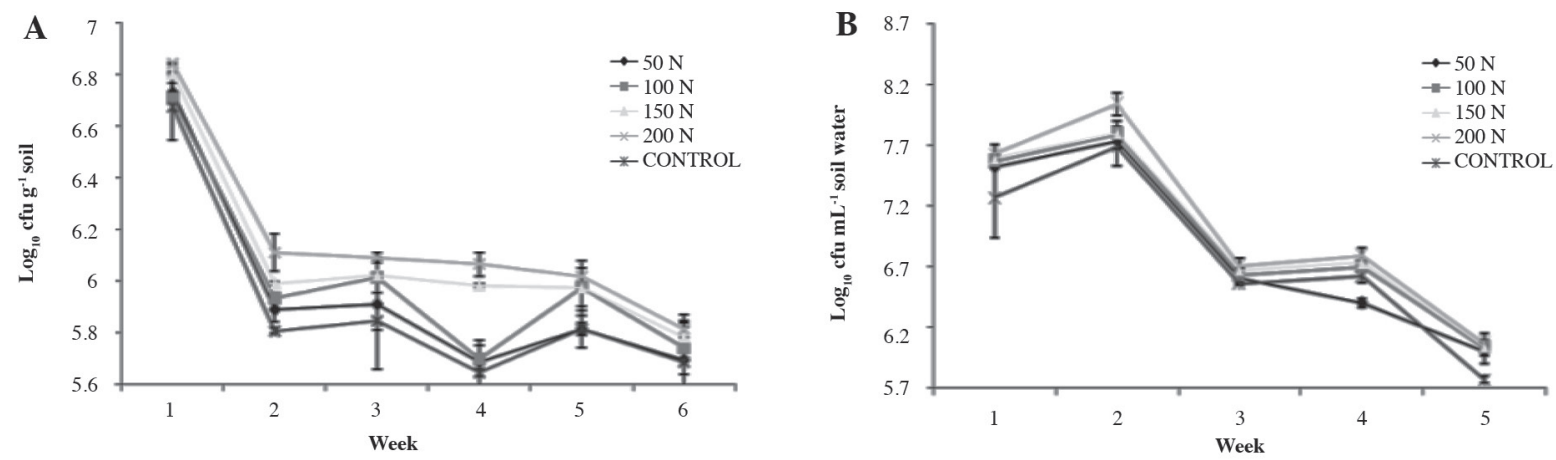

Figure 1. Effect of urea-N on population of Sb16 in soil (a) and soil standing water (b). Bars indicate standard error $\mathbf{n}=3$.

There were significant differences in population at first, third, and sixth week with increasing rates of urea-N. This could be due to the utilization of available $\mathrm{N}$ for cell growth. During the high bacterial growth in urea-N treatments, gelatinous material was observed to form in the soil layer of the incubation flask. The material could be the extra cellular polysaccharide produced by bacterial cells. Polysaccharide is a polymer that plays an essential
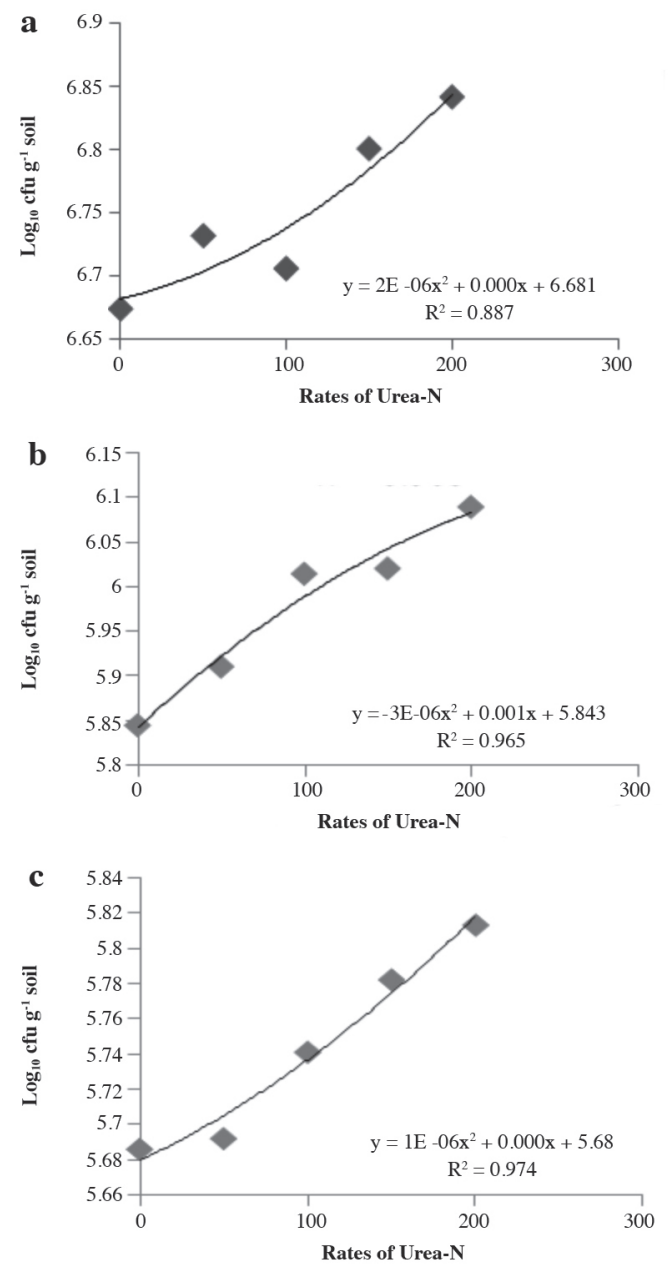

role for bacterial growth and survival (Castro et al., 2008), it protects cell from desiccation and help in $\mathrm{N}_{2}$ fixation by preventing high oxygen $\left(\mathrm{O}_{2}\right)$ tension (Kumari et al., 2009).

\section{Soil chemical properties}

The $\mathrm{pH}$ was significantly affected by different levels of urea-N (Figure 3). Soil pH increased after first week of incubation and stabilized thereafter. After the first
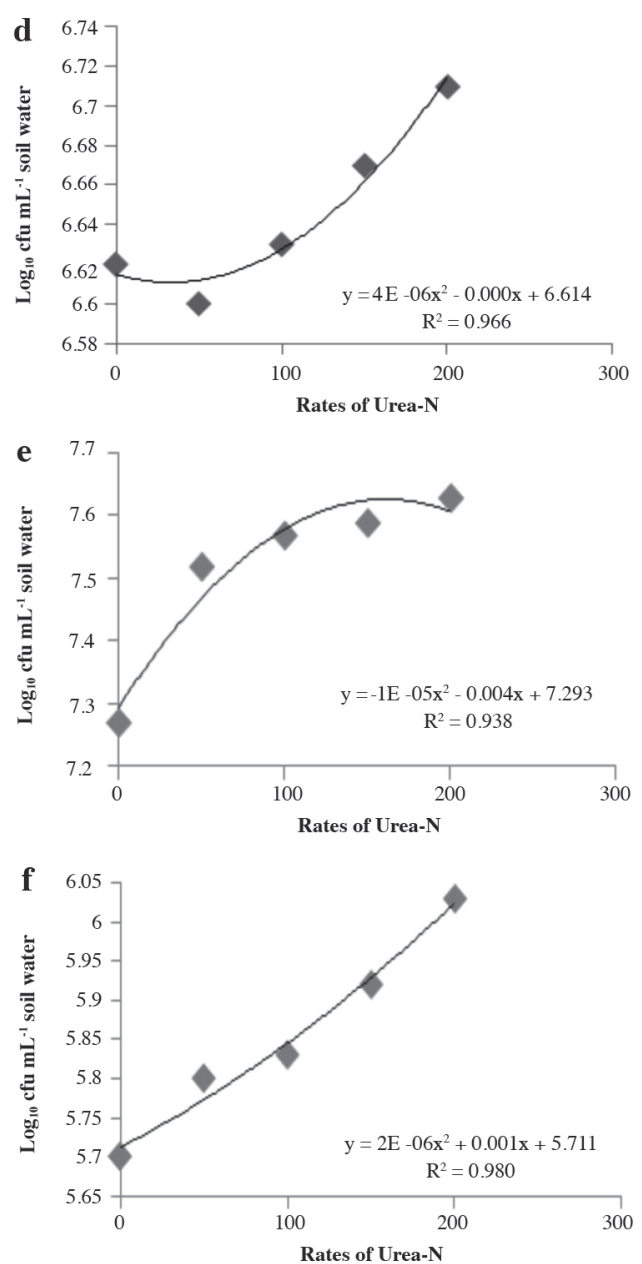

Figure 2. Bacterial population at different levels of urea-N in soil at first week (a), third week (b), sixth week (c), and in soil standing water at first week (d), third week (e), and sixth week (f). 

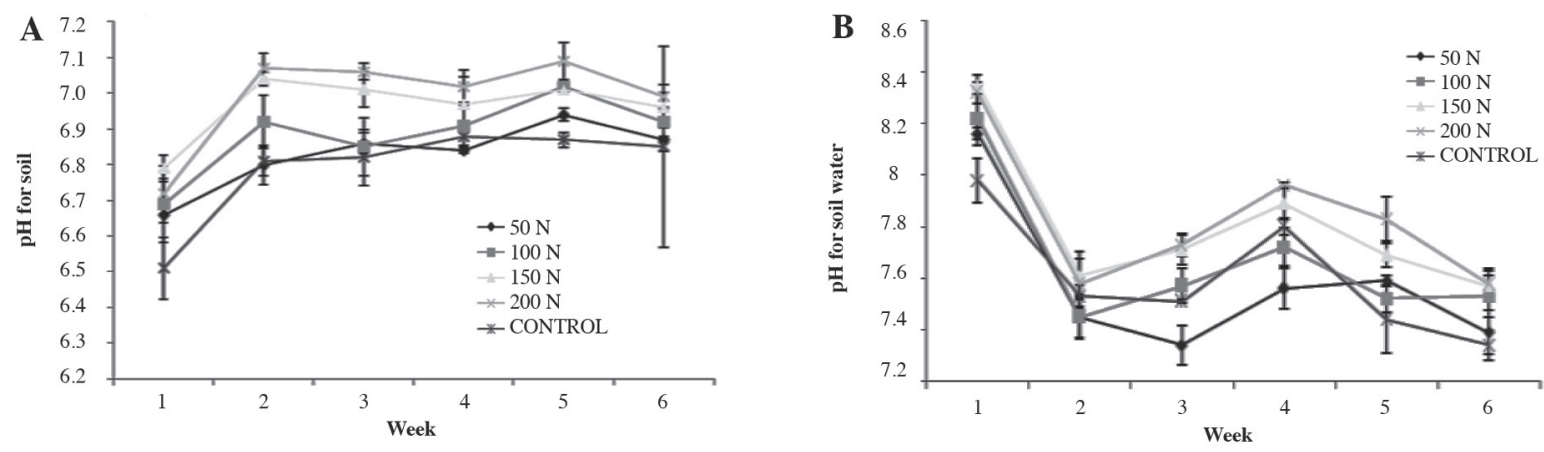

Figure 3. Effect of urea-N on soil pH (a) and soil standing water $\mathbf{p H}$ (b). Bar indicates standard error $\mathbf{n}=3$.

week of incubation, soil $\mathrm{pH}$ increased from 6.7 to 7 and $\mathrm{pH}$ of control soil was lower than the other treatments. Soil treated with urea-N had higher $\mathrm{pH}$ than control as presence of high $\mathrm{NH}_{4}{ }^{+}$concentration in the soil increased $\mathrm{pH}$. Optimal $\mathrm{pH}$ for $\mathrm{N}_{2}$ fixation is 5-8 (Leigh, 2002). The consistencies of soil $\mathrm{pH}$ provide a stable environment for the growth of Sb16 that increases the survival and activity of Sb16 in soil and water.
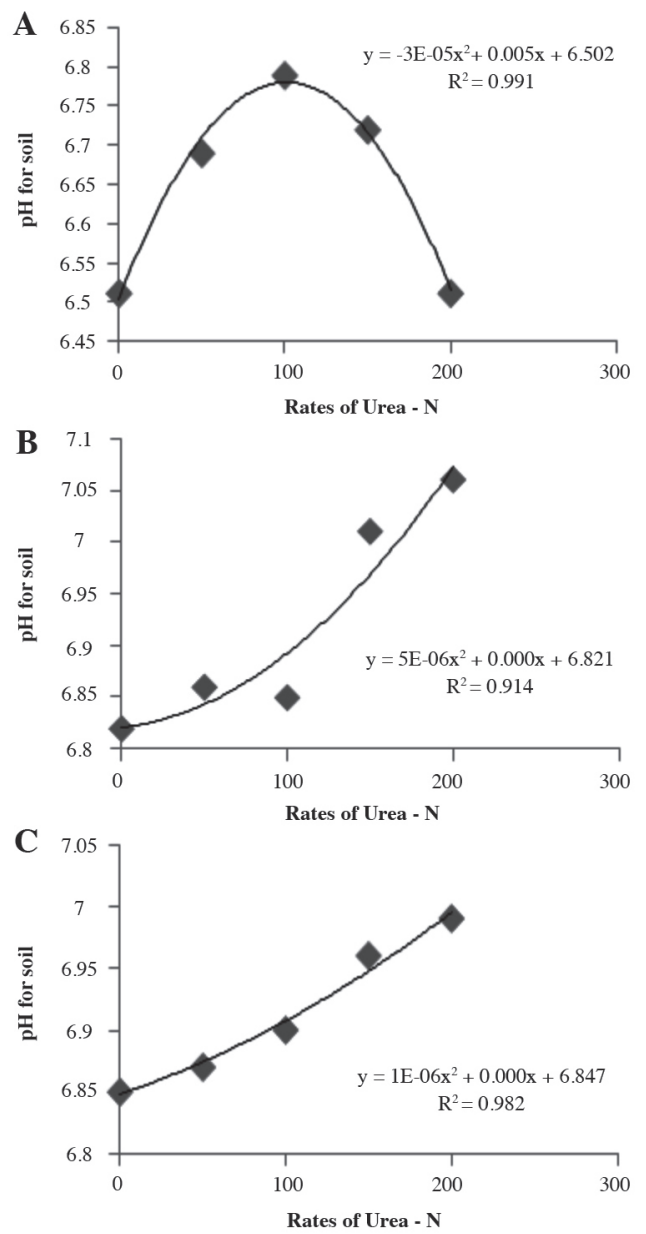

Figure 4. pH changes at different levels of urea-N in soil at first week (a), third week (b), sixth week (c), and in soil water at first week (d), third week (e), and sixth week (f).
The $\mathrm{pH}$ of soil-standing water was higher compared to $\mathrm{pH}$ of soil which ranged from 7.4 to 8.4 (Figure $3 \mathrm{~b}$ ). The $\mathrm{pH}$ change was probably due to the formation of ammonium ion in the soil standing water. Ammonium ion can also be formed through $\mathrm{N}_{2}$ fixation by $\mathrm{Sb} 16$. The $\mathrm{pH}$ of soil and soil water in the first, third, and sixth weeks of incubation increased significantly with increasing rate of urea-N (Figure 4).
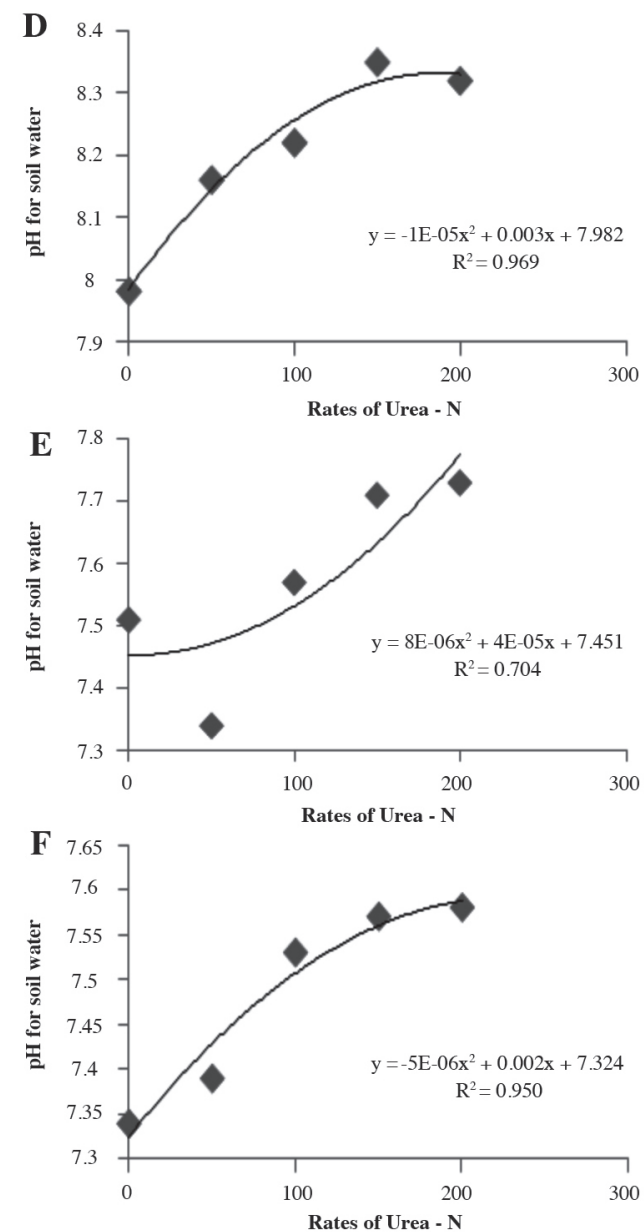
There were significant effects of different levels of urea- $\mathrm{N}$ on total soil $\mathrm{N}$ content. Total $\mathrm{N}$ in soil decreased with increasing time of incubation (Figure 5). Total $\mathrm{N}$ content in soil and soil water decreased with increasing incubation time as it was used up by the applied bacteria. Other important factors may regulate $\mathrm{NH}_{3}$ loss as the $\mathrm{pH}$ of the soil solution was high. However, an increasing trend of total $\mathrm{N}$ in the soil standing water observed at the $5^{\text {th }}$ and $6^{\text {th }}$ week of incubation which showed the biological $\mathrm{N}$ fixation activity.

\section{Concentration of IAA}

The IAA production by bacteria was significantly affected by urea-N levels. Significantly high amount of IAA was produced in the control treatment and lowest amount produced in the $200 \mathrm{~kg} \mathrm{ha}^{-1} \mathrm{~N}$ applied treatment. The IAA concentration in the soil standing water was higher than in soil fraction. The initial IAA concentration in soil ranged from 1.5 to $2 \mathrm{mg} \mathrm{g}^{-1}$ and it was observed to decrease with increasing time of incubation (Figure 6). The amount of IAA produced in this study was comparatively low. Previously the Sb16 was shown to produce high amount of IAA in the presence of tryptophan (Naher et al., 2009). The low concentration of IAA could be due to the presence of low amount of precursor, L-tryptophan in the soil and water. The presence of IAA stimulating amino acid such
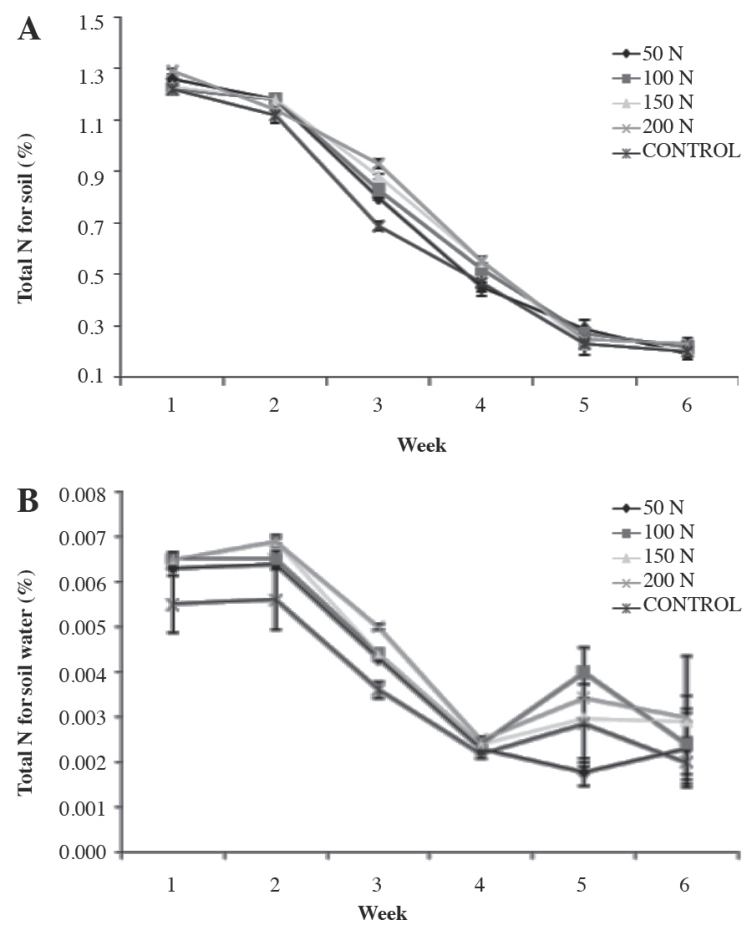

Figure 5. Effect of urea- $N$ on total $N$ content in soil (a) and soil standing water (b). Bar indicates standard error $n=3$. as L-alanine, L-asparagine, and L-lysine have been reported to be present in root exudates, which stimulate formation of IAA in soils (Naher et al., 2008).

A significant decrease in IAA concentration in the soil and soil standing water found with increasing rates of urea-N (Figure 7) which might be due to less activity of the added microbes.

\section{CONCLUSIONS}

Application of different rates of urea-N significantly increased population of diazotrophic strain Sb16. The total $\mathrm{N}$ decreased until sixth week either it was used by the bacteria as a nutrient or $\mathrm{NH}_{3}$ lost during incubation time. Application of urea-N significantly reduced the IAA production. The higher IAA value in control $\mathrm{N}$ treatments proved that higher doses of nitrogen reduced bacterial activities but did not hamper its growth.

\section{ACKNOWLEDGEMENT}

The authors are grateful to the Ministry of Science, Technology and Innovation (MOSTI) for Science fund project and Long-term Research Grant Scheme (LRGS) fund for Food Security and Ministry of Higher Education Malaysia.
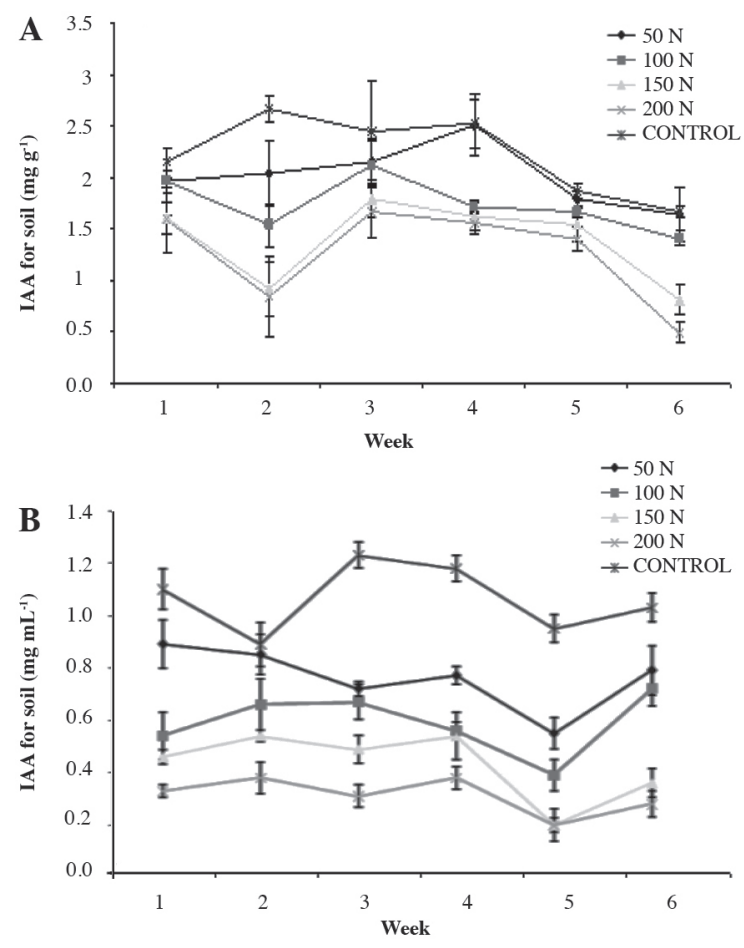

Figure 6. Effect of urea-N on indoleacetic acid (IAA) production of Sb16 in soil (a) and soil standing water (b). Bar indicates standard error $n=3$. 

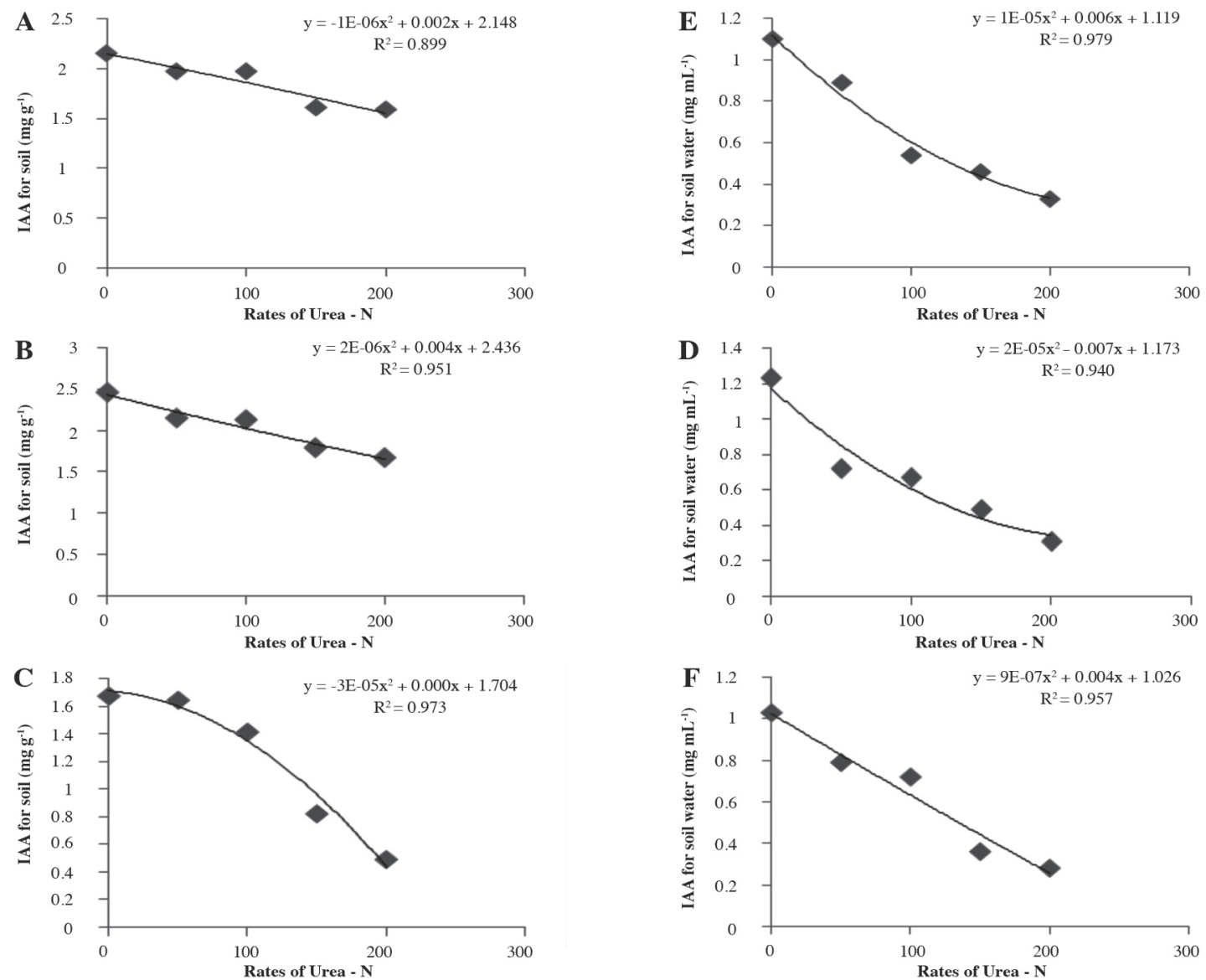

Figure 7. Effect of urea-N on indoleacetic acid (IAA) production of Sb16 in soil at a) first week, b) second week, c) third week, and in soil water at e) first week, d) second week, and f) third week.

\section{LITERATURE CITED}

Bohlool, B.B., J.K. Ladha, D.P. Garrity, and T. George. 1992. Biological nitrogen-fixation for sustainable agriculture - a perspective. Plant and Soil 141:1-11.

Castro, C.D., A. Molinaro, R. Lenzetta, A. Silipo, and M. Parrilli. 2008. Lipopolysaccharide structure from Agrobacterium and Rhizobiaceae species. Carbohydrate Research 343:1924-1933.

Döbereiner, J., and F.O. Pedrosa. 1987. Nitrogen-fixing bacteria in non-leguminous crop plants. Springer-Verlag Science Technology, Madison, Wisconsin, USA.

George, T., J.K. Ladha, R.J. Buresb, and D.P. Garrity. 1992. Managing native and legume-fixed $\mathrm{N}_{2}$ in lowland rice-based. Plant and Soil 141:69-91.

Gordon, D.A., and R.P. Weber. 1951. Colorimetric estimation of indole-3-acetic acid. Plant Physiology 26:192-195.

Junior, F.D.R., R.M. Veronica, S. Urquiaga, and J. Dobereiner. 2000. Influence of nitrogen fertilization on the population of diazotropic bacteria Herbaspirillum spp. and Acetobacter diazotrophicus in sugar cane (Saccharum spp.) Plant and Soil 219:153-159.

Kennedy, I.R., A.T.M.A. Choudhury, and M.L. Kecskés. 2004. Nonsymbiotic bacterial diazotrophs in crop-farming systems: can their potential for plant growth promotion be better exploited? Soil Biology Biochemistry 36:1229-1244.

Kumari, B.S., R.M. Ram, and K.V. Mallaiah. 2009. Studies on exopolysaccharide and indole- acitic-acid production by Rhizobium strains from Indigofera. African Journal of Microbiology 3:10-14.
Leigh, G.J. 2002. Nitrogen fixation at the millennium. Elsevier Science, London, UK.

Naher, U.A., O. Radziah, M.S. Halimi, Z.H. Shamsuddin, and I. Mohd Razi. 2008. Effect of inoculation on root exudates carbon sugar and amino acids production of different rice varieties. Research Journal of Microbiology 3(9):580-587.

Naher, U.A., O. Radziah, M.S. Halimi, Z.H. Shamsuddin, and I. Mohd Razi. 2009. Influence of root exudate carbon compounds of three rice genotypes on rhizosphere and endophytic diazotrophs. Tropical Agriculture 32:209-223.

Naher, U.A., O. Radziah, Z.H. Shamsuddin, M.S. Halimi, I. Mohd Razi, and A. Rahim. 2011. Effect of root exuded specific sugars on biological nitrogen fixation and growth promotion in rice (Oryza sativa). Australian Journal of Crop Sciences 5:1210-1217.

Othman, O., U.A. Naher, and S.I.A. Hamed. 2012. Effect of Paraquat on growth of diazotrophic strain Stenotrophomonas maltophila in flooded soil. African Journal of Microbiology Research 6:49394944.

Saikia, S.P., and J. Vanita. 2007. Biological nitrogen fixation with non-legumes: An achievable target or a dogma? Current Science 92:317-322.

Sarwar, M.M., A. Arshad, D. Martens, and W.T. Jr. Frankenberger. 1992. Tryptophan dependent biosynthesis of auxins in soil. Plant and Soil 147:207-215.

Somasegaran, P., and H.J. Hoben. 1985. Methods in legumeRhizobium technology. University of Hawaii, College of Tropical Agriculture and Human Resources, Honolulu, Hawaii.

Wang, Z.P., R.D. DeLaune, C.W. Lindau, Patrick, and W.H., Jr. 2004. Methane production from anaerobic soil amended with rice straw and nitrogen fertilizer. Fertilizer Research 33:115-121. 